\title{
DISCUSSION
}

\section{Fundamental gap in fundamental biology}

\author{
V. A. Kordium, V. I. Andrienko, O. A. Maslova, N. S. Shuvalova, D. M. Irodov, \\ T. A. Ruban, E. M. Sukhorada, L. I. Likhacheva, S. P. Shpilevayar
}

Institute of Molecular Biology and Genetics, NAS of Ukraine

150, Akademika Zabolotnoho St., Kyiv, Ukraine, 03680

kordium@imbg.org.ua

\begin{abstract}
The article raises the problems of intracellular spatial and temporal organization of metabolism, signaling, and energy supply of these processes. To provide cell functions, the enzymes of metabolic chains, molecules of signaling pathways, and macroergs (as units of molecular interactions, accompanied by energy consumption) should find their partners and get their precise spatial relationship. The current views are based on ideas of compartmentalization of all processes as local sites of cellular matrix membrane, where specific stages of different metabolic cycles take place. The assembly of complexes of macromolecules in the number and combinations, required for their adequate functioning in the space of a cell, is generally described as intracellular transport of vesicles, implemented by mobile elements of cytoske- leton. Inside the vesicle there is «effective load»-macromolecules. The membranes of these vesicles fuse with specific sites of the matrix membranes and therefore relocate macromolecules. Neither calcula- tions nor assumptions allow explaining precise formation of enzymatic chains, their interaction, signaling, etc. on this basis. Such transport of macromolecules (inside vesicles) enables solving other tasks. The concept of search-and-address systems in the form of space-scanning micro vesicles is proposed and well-grounded for purposes of searching for partners, forming chains and complexes, and building compartments. The micro vesicles collect corresponding chains of enzymes, signaling, and ensure the interactions on their surface. These micro vesicles are exactly those compartments, which provide for both precision of processes and their relationship.
\end{abstract}

Keywords: metabolism, cell, compartmentalization, vesicle, trans- port of macromolecules, precision of processes.

At the dawn of molecular biology there was a humorous slogan "From false knowledge ? to true ignorance!" Regardless of its apparent ridiculousness, it was precise reflection of the state of science at the time. Something like that can be extrapolated to

(C) Institute of Molecular Biology and Genetics, NAS of Ukraine, 2011 modern fundamental biology, not in a sense that our knowledge is false or little, though. The progress is terrific and constantly accelerates, therefore new phenomena, new processes, new functions, etc. are discovered. The amount of experimental material goes beyond the possibility of its thorough evaluation (let alone its comprehension). And all this is the 
background of utmost clarity for the paradox of a cognition level under development

As the information, from experiments to global ideas, about the cell as a central unit of all living on the Earth accumulates, the real functioning of a real cell (i.e. coordinated combination of processes inside it, running in space and time) is less and less clear. Moreover, any attempt to imagine how all this may be performed in a cell, results in inevitable and absolutely evident conclusion on its incredibility. Let us analyze it in detail, let us view the cell "as it is in fact".

Previously the study of the cell was going on so that a critical gap occurred. The development of microscopy techniques resulted in almost thorough description of the cell and its structures. However, in these studies the cells were fixed, as microscopic resolution for the analysis of living material was very low. So the entire cytology looked like a momentary section of structural organization of any investigated subject. This kind of studies allowed reconstructing the cell, but only as a momentary section as well. On the contrary, the object of biochemical investigations were processes, i.e. enzymatic reactions, metabolism cycles, stages of biosynthesis, energy supply, etc. Gradually there appeared the functional picture with apotheosis of a full-size map of metabolism.

The sphere of molecular biology, like at the time of its creation, still comprises detailed studies on the structure of macromolecules, their spatial organization and its dynamics, interactions of macromolecules, changes in spatial structure due to different interactions, etc.

The concept of a cell became more complicated, there appeared ideas on regulation, signaling chains, cycles; specific processes were integrated into functionally unified signaling-metabolic axes. The discovery of the world of low-molecular RNA brought even more variety into the picture of the cell life.

The development of methods of molecular genetics allowed revealing informational and phenomenological sequences of processes, and gene engineering enabled the realization of this knowledge into the obtaining of necessary products. As new ideas were adequately approved in experiments and realized in practice, everything came down to the accumulation of new data, computer simulation, construction of required molecules, their introduction into cells and analysis of events, occurring thereby. It seems that there was an unspoken assumption that everything occurred "by itself".

As a result, the most important thing, defined by the term "by itself", was out of focus. This "by itself" was not even studied, as it occurred "by itself". Meanwhile, it meant something fundamental - spatial and temporal organization of all processes.

The first thing, which became clear in the sense of "it cannot occur just for the sake of it", was the organization of metabolism processes [1]. Actually, it is enough to look at the maps of metabolism, their specific chains, coupling of chains, that an obvious question arises - how can all this be realized in the cell? This question was sidetracked by general answers like: everything is compartmentalized in the cell, each compartment has its "own stuff", the coupling occurs via contacts of compartments, etc. [2]. Then, there was "detailed elaboration" like: enzymes do not swim even in compartments, they are fixed on membranes not wherever, but to form cycles. Finally, when the kinetics of processes and the level of reactivity of intermediates were estimated, and the probability of events was evaluated, it became clear that current ideas did not help to solve the problem - due to the absolutely necessary metabolism everything in the cell would instantly transform into the chaos of all-destructive reactions. Therefore, in order to explain the absence of such chaos, some prerequisite of functioning of all the required metabolic chains and their couplings was introduced. Pursuant to this prerequisite, all enzymes in cycles (of any degree of complexity, branching, coupling, etc.) obtain the intermediate of metabolism from a previous enzyme, correspondingly, transmit it to a following enzyme, exactly like "from hand to hand" [3], i.e. from the active centre of one enzyme directly to the active centre of the other. The detailed mechanisms (not just proposed in general but confirmed by experiments or at least theoretical estimations of distances between active centers, reaction rates, locations of chain enzyme molecules, etc.) to explain above mentioned are not known. However, in the real cell the mechanism "from hand to hand" does exist though we do not know almost anything about its organization in space and dynamics. 
One more element of processes is their energetics. The intermediate products, formed in all kinds of reactions, like different radicals, peroxides, molecules, containing tense bonds, etc., are absolutely all-destructive. Their number is immense. In order to avoid momentary self-destruction, the precision of coupling for all the processes should be close to theoretically absolute, which exactly occurs in the cell. But it is completely impossible even to imagine a picture like this with the consideration of rates of all processes, mutual spatial configurations, accuracy of what happens etc., in the terms of distances (angstroms and tenths of angstrom) and temporal parameters of individual processes (milli- and microseconds), in particular, because each cycle has many individual processes. Some cubes, circles, triangles are drawn (like in children's pictures) or chemical reactions, catalyzed by enzymes, are simulated, and it is declared seriously to be a real picture of the cellular processes.

Finally, it has come down to the regulation. Somehow the cell governs all the processes. All the processes inside it are in interconsistency mutually coordinated. The elucidation of how it occurs led to establishment of the most complicated signaling chains and cascades, covering the whole cell and everything, occurring in it [4]. They are the chains with direction of processes, linear, organized into cascades, at the level of interacting cascades, increasing or canceling already going signals, etc. Here even the abstract idea of "from hand to hand" is insufficient. It takes just one look at them, one projection to the maps of metabolism and energetics, and then one introduction into the cell in thoughts or in silico, to understand that it is not even funny to assume that all this may function in an accurate, definite, precise, time-wise unrestricted and most reliable way "by itself". Along "came" low-molecular RNAs which additionally control, regulate, check and provide for everything. It is being drawn at the level of abstract "molecule-molecule" interactions. It is even being calculated somehow. In vials - in vitro system - it is being experimentally proven. Specific (and adequate) effects are being obtained by introduction of their specific representatives (certain genes, proteins, RNA) into cells. "By itself" works without any failure. Still, in investigations this "by itself" is completely ignored, silently acknowledged by the principle of "black box": to introduce / to obtained, because nobody even attempts to project this onto the cell in its real dimensions of space and time. Meanwhile all these signaling chains, cascades, and microRNA have to be regulated in their turn: time of formation, sequence of interactions, localization, amount, etc.

As for all these cycles and cascades, they function in the cell not as a sum of single macromolecules, but rather as complexes, consisting of many (sometimes dozens) separate macromolecules [5]. And in many cases (may be even in majority) these very complexes are labile and re-forming. Each complex has its own composition of macromolecules, they should be chosen from the synthesizing pool, collected within the whole cell (where they are synthesized), correctly space-oriented, somehow localized in a proper place and at proper time. Once the size of molecules of signaling cascades is related to the distance which they should go to provide regulation, the impossibility of this happening due to "by itself" is quite evident (Fig. 1). Meanwhile, all this "by itself" is not even discussed let alone being studied. So the whole molecular biology actually appears to be statics. The accurate dynamics is studied only at the level of conformational transitions of specific macromolecules or their complexes, that are "ready-made", brought together constituents. However, it is not clear how they all gather correctly. For even if their presence in microvolume in ready qualitative and quantitative composition is assumed, how are such complexes formed correctly out of random mutual localization and orientation? So, genomics, proteomics, metabolomics, and regulomics, taken together, do not solve (and cannot solve) in principle the fundamental problems of the cell life in any conceptually accepted schemes, in any experiments, set according to these schemes, in any in silico current notions, no matter how much new data are accumulated. After all, it will be exhaustively revealed what exactly the cell consists of, what macroand other molecules are in it, what cycles, chains, and cascades are in them, and which macromolecules everything consists of. Still all this will be just statics, like warehouses of ready products, assembled joints, and even (one day) the whole "item" - the cell. It will only enhance the understanding of scope of inevitable 


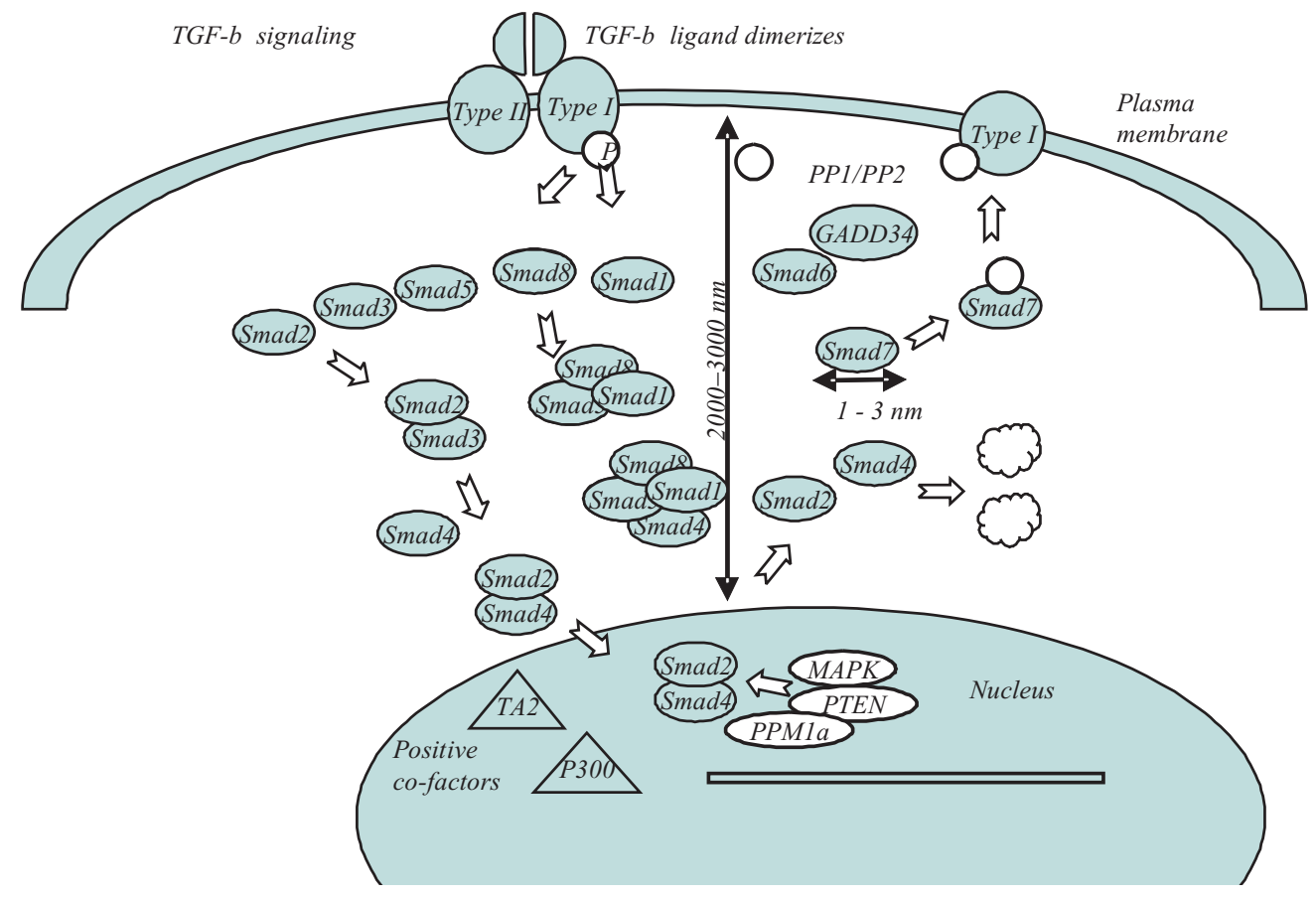

Fig. 1. Size ratio and the distances in the cell (simplified scheme of TNF- $\beta$ signalling)

chaos, once "everything" starts functioning. "Ready-made" stuff is quickly destroyed and requires replacement (self-renewal), but it is incomprehensible how it happens in space and time.

The problem of the "substrate", where cellular macromolecules are located, is very complicated. In fact, there is a lot of water in mammalian (including human) cells, but, most likely, almost all of it is structured, i.e. adsorbed, kind of "fixed" on macromolecules. Although determination of the distribution rate for both macro- and small molecules ("diffusion constants") in the cell shows rather measurable quantities, they do not explain anything. Let us also note that these data were obtained only on actively metabolizing cells. There have been no similar measurements for resting cells (either they have not been performed, or they have not given any "correct results"). And there are no data about the mechanisms of such translocation of molecules in actively metabolizing cells) The very term "diffusion" and the mechanisms of the process, defined by this term, have been taken from physics "per se".
Let us project the metabolic processes onto the cell with its dynamism and "diffusion constants" of macro(and other) molecules. With the rates of all these processes and movements of formed products (according to "diffusion constants"), the chaos, instantly transforming the cell into automicrohomogenate, is obvious. And this is not "general considerations". It is confirmed by precise calculations on the basis of experimental data. According to existing estimates, the values obtained may be presented on example of diffusion coefficient of bovine serum albumin with molecular mass (m.m.) of $68,000 \mathrm{kDa}$, labeled with fluorescein, $10^{-8} \mathrm{~cm}^{2} / \mathrm{s}[6]$ :

In fibroblast cells, $5{ }^{\circ} \mathrm{C}$ 0,3

In fibroblast cells, $22^{\circ} \mathrm{C} \quad 1,0$

In fibroblast cells, $37^{\circ} \mathrm{C} \quad 1,6$

In fibroblast cells, previously

treated with colchicine, $5{ }^{\circ} \mathrm{C} \quad 1,1$

In $61 \%$ solution of sucrose, $30^{\circ} \mathrm{C} \quad 1,0$

In the buffer, $20^{\circ} \mathrm{C} \quad 68,0$ 
What happens next, according to the ideas on translocation of molecules in the cell "by themselves", is clearly illustrated by the following calculations on the example of BSA:

At $t=37$ ? $\mathrm{C}$ the diffusion coefficient of BSA in fibroblasts is $1.6 \cdot 10^{-8} \mathrm{~cm}^{2} / \mathrm{s}$. This is a way of $1.6>$ in $1 \mathrm{~s}$ through one square unit. With the average diameter of protein molecule of 20 > it will move for 0.08 of its diameter per $1 \mathrm{~s}$.

The diffusion coefficient of $>4 \cdot 10^{-8} \mathrm{~cm}^{2} / \mathrm{s}$ was found for a small molecule (fluorescein, m.m. $=374$ Da). If the rate of treating the substrate in metabolism chains for 100 cycles $/ \mathrm{s}$ is taken for some average value (1 cycle/0.01s), during this time the substrate will cover the distance, which somewhat exceeds 0.04 , and during $1 \mathrm{~s}>4$ >. At these rates the products are accumulated around active centers of the enzymes. Therefore, it would take a long time to synthesize a protein molecule.

Now, let us discuss the energetics. If accept the mass of average cell as $10^{-9} \mathrm{~g}$, its volume will make $1,000 \mathrm{~mm}^{3}$ at specific gravity of $1 \mathrm{~g} / \mathrm{ml}$. Let us also take that in this average cell there are $10^{9}$ macromolecules with enzymatic activity. Let us consider such situation. At the average molecular mass of the protein of $50 \mathrm{kDa}$ the total mass of $10^{9}$ protein molecules is equal $8.3 \cdot 10^{-11} \mathrm{~g}$, which corresponds to a quite admissible part (8.3\%) of the accepted mass of an average cell. At the average rate of enzymatic reactions of 100 cycles per $1 \mathrm{~s}$ converted to 24 hours, this corresponds to $8.64 \cdot 10^{15}$ molecules of products of these reactions. It follows from the calculation: 100 (cycles per $1 \mathrm{~s}$ ) $\bullet 86,400$ (number of seconds in 24 hours) $\bullet 10^{9}$ (number of molecules with enzymatic activity in one cell) $=8.64 \cdot 10^{15}$. The predominant majority of enzymatic reactions in the cell produce intermediates in different cycles. They all have high reactivity and immediately overtake further way of transformations. At the average metabolite mass of $34 \mathrm{Da}$ (this is $\mathrm{m} . \mathrm{m}$ of hydrogen peroxide), $\sim 487.6 \cdot 10^{-9} \mathrm{~g}$ of metabolites are formed in the accepted average cell during 24 hours, which is almost 500 times bigger than the cell itself with the mass of $10^{-9} \mathrm{~g}$ and the volume of $1,000 \mathrm{Mm}^{3}$. The detailed calculation: 34 (m.m. of the conventional metabolite, Da) $\cdot 1.66 \cdot 10^{-24}$ (mass of $1 \mathrm{Da}$, converted into grams) $\cdot 8.64 \cdot 10^{15}$ (number of conventional intermediate metabolites $)=487.6 \cdot 10^{-9} \mathrm{~g}$.

Surely, all this is in dynamics - in constant transformation. But in total, i.e. having calculated everything that was formed and existed before further transformation along the cycles, this value seems to be true. It is no need to discuss what might happens in case of the translocation of all the participants "by itself", without any special mechanisms for all the events in the cell. And by all the "current notions" such a cell can neither appear, nor exist at all. Meanwhile, the cell "actually" lives and functions with the highest precision, reliability and efficiency.

To turn from general phrases (like "proteins find their partners") to attempts (at least attempts) to find, identify, predict actual mechanisms of spatial and temporal implementation of cellular processes, let us formulate the tasks, which can be performed by this mechanism. They are targeted spatial and temporal translocation of macromolecules, targeted spatial and temporal search for partners of functional complexes, their association in required ratio, delivery to "destination place" just in real-time scale. Finally, the regulatory cascades, also collected and mutually spatially located with functional relationships and junctions should be provided by the same mechanism or other necessary mechanisms. Moreover, they should be functionally united in space and time with enzymes of different metabolic chains or corresponding genes so that the regulation can be efficient. And all these tasks should be constantly performed during the whole lifetime of the cell, or, which probably is more adequate, during its active state. Considering the current terminology ("intracellular transport", "transport pathways", "intracellular sorting of proteins", "delivery", "compartments", etc.), it is possible to decide that such terminology includes the definitions of corresponding mechanisms. But per se, such definitions usually do not describe complete nature of given process or phenomenon.

The first key information in determining the mechanism of "intracellular sorting of proteins" was the discovery of a leader peptide [7]. Many proteins are synthesized with additional amino acid sequence at $\mathrm{N}$-end. It is specifically recognized by membranes of 
intracellular organelles and transfers a whole protein molecule through membranes later being cut off by specialized membrane-bound enzymes. This is how the composition of proteins, required for functions of organelles, is formed [8]. The exocytosis is operating with similar mechanism [9]. However, it is not discussed exactly how proteins reach a necessary organelle membrane, which should be recognized by a leader peptide, tropic to it. As for the movement to the external membrane and between organelles, between compartments of cytoplasm, it is described in much detail and studied almost exhaustively [10]. The microvesicles, which fission from Golgi apparatus, perform this function $[11,12]$. Due to the leader peptide a target protein penetrates into the vesicle while the vesicle itself gets "dressed" in so called "recognition proteins" [13], and then this transport system migrates to the target.

This notion was formed rather long ago [14], and it did not change since that time. Only precise elements were clarified - composition of proteins, covering these vesicles, their binding to mobile filaments, etc. $[15,16]$. Here is the quote from the publication, dated 2010. "Universal feature of eukaryotic cells is the presence of intracellular membrane compartments, which exchange lipids and proteins via intermediate membrane-limited transport carriers, such as vesicles or tubulo-vesicles (usually described as "transport carriers"). Intracellular trafficking requires close coordination between the formation of transport carriers from the donor membrane, their movement along the cytoskeleton, and their docking and fusing with the correct acceptor membrane" [17]. All this undoubtedly takes place, has been studied in detail and plays some role in the cell life. However, we think it has nothing to do with the central problem of spatial and temporal organization of the cell life, analyzed above. The described transport performs absolutely different functions, and due to the nature of its organization it cannot provide for the formation, interaction, dynamics of metabolic and regulatory (signaling) chains, cycles, and cascades. In reality it is not even an attempt to explain what happens, but the attempt to avoid it. Here what really happens is unobtrusively transferred to what is believed to happen. Even the very term "compartment" and what it means are rather indefinite.
They are aimed at explaining the spatial localization of any processes, events, and states. To confirm this, "unquestioned compartments" such as mitochondria, lysosomes, peroxisomas are brought forth as well as a few other so called "understandable" structures. But where are the compartments of biosynthesis of amino acids, nucleotides, lipids, etc.? And how are they thought to be located, besides general considerations like "localization on membranes"? Where exactly are all these compartments of metabolism chains in the cell? In order to start searching for real mechanisms, let us look at the cell once more and pay special attention to what is usually taken for granted - "it is as it is", "that is how life is organised", etc.

Let us start with the most "banal" - composition of proteins in the cell, and let us demonstrate how the proteins are distributed among the processes using the example of mesenchymal cells [18]:

Functional group $\quad$ Total number of proteins, $\%$
Cytoskeleton and movement

Metabolism

Protein biosynthesis, folding

and degradation

Biosynthesis of nucleotides

and integrity of genome

Cell signaling
36

6

9
The entire metabolism of the cell is supported by $22 \%$ of proteins from the total composition (nomenclature) of all cellular proteins. The proteins biosynthesis, their assembly and degradation are performed by $27 \%$. And the share of proteins, organizing the mobility and cytoskeleton (actually the proteins of movement, although by somewhat different mechanism ? polarization-depolarization), is as much as $36 \%$ of all the cellular proteins. Why? What is this function, which requires the "elements" of trafficking more than the constituents, evident in their absolute relevance and variety, "most-most" important, main, basic, fundamental, etc., sustaining the cell life? Moreover - the ones, constituting practically the whole cell as a "life unit", i.e. maintaining its self-sufficiency. 
Because all the proteins of their own biosynthesis, assembly and degradation along with the proteins of biosynthesis and integrity of the nucleic constituent (DNA and RNA, taken together) compose $33 \%$ while those relative to movement of all kinds - $36 \%$. And the regulation of all this is more than simple, though it ensures the maximal rate of processes. Certainly, this question is studied in detail, and the role, attributed to "proteins of movement", is adequate - the function of moving. But there follows limiting concretization what to move? Here the list is rather long - both the cell itself and its inner structures move - nucleus, mitochondria, lysosomes, vacuoles, vesicles, described for different kinds of transport of the substances within them [19]. Ambiguity starts at considering "why?" As for the cells, their trafficking in the organism is clear. Vesicles move their content among compartments inside the cell, as well as outside-in and inside-out. The functions of trafficking of all the rest are already being described in general. And that is all. It seems to be rather insignificant as for the constituents dominating in the cell.

While observing the life of mesenchymal cells, we discovered a special type of structures. They are presented as numerous highly dynamic and mobile

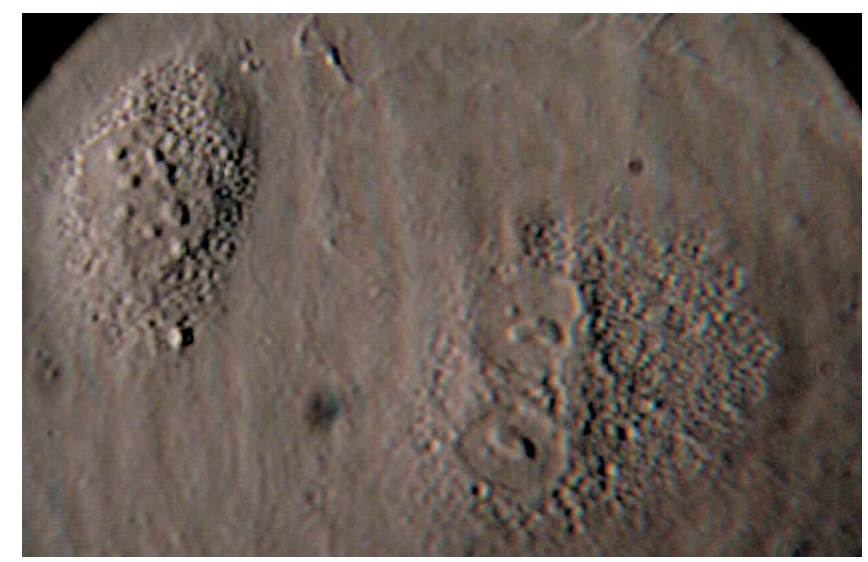

Fig. 2 Highly dynamic and mobile microsize units by interference microscopy

microsize units (Fig. 2). Their size is random in the range of tenths of micrometer (Fig. 3), and the lifetime varies in a broad range. Both the direction and speed of movement fluctuate even for one formed unit (Fig. 4). The unit number depends on the location in the cell -
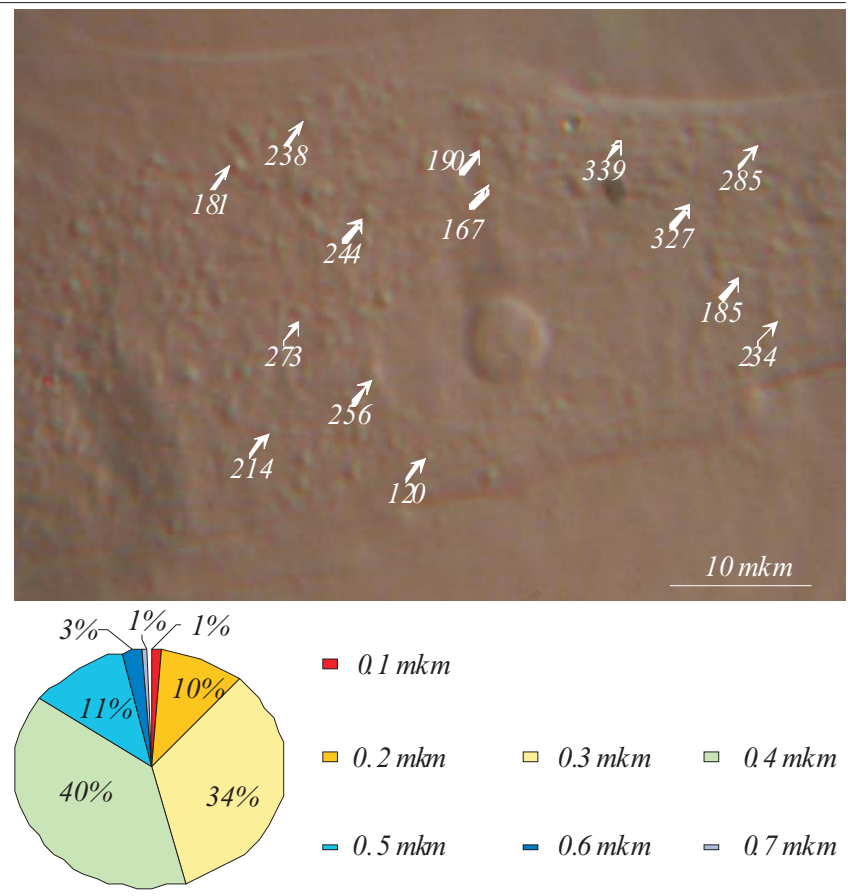

Fig. 3 The size of units is random in the range of tenths of micrometer

maximum around the nucleus diminishing toward the periphery. Thus, according to the direct determination, average concentration per $1 \mathrm{~mm}^{2}$ (in the focal plane of

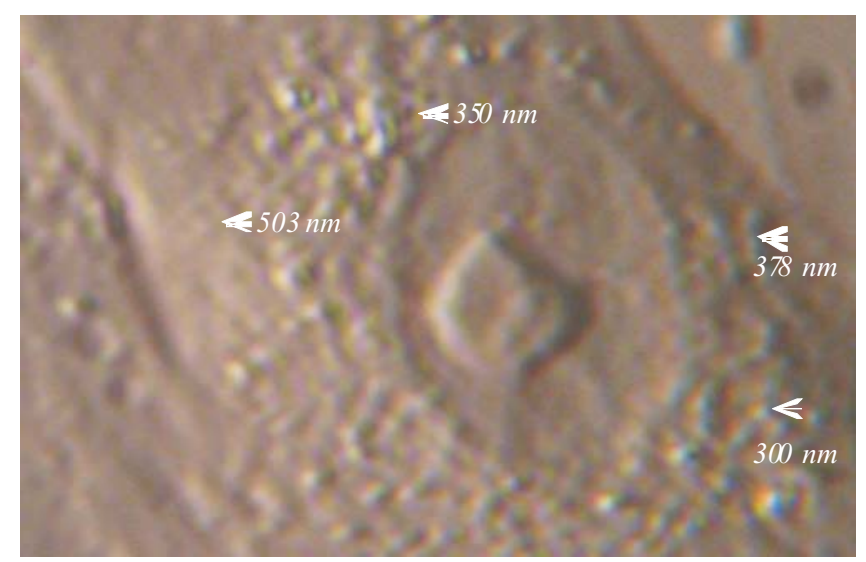

Fig. 4 Microfilme $5 \mathrm{~s}$. (Speed of movement fluctuate even for one formed unit )

the lens) in a typical cell is 2.5 - close to the nucleus, 1.5 - between the nucleus and cellular membrane (along the short axis of the cell), and 0.7 - in the zone adjacent to membrane. The observations of these structures and the character of their behavior allowed 
us to assume that their functions are: search, selection, assembly, collection of corresponding proteins and their complexes, interactions of these proteins and complexes, as well as their transport and target delivery to "the destination place". To perform these, they should have "catching structures" peculiar macromolecular "platforms" for binding the macromolecules recognized according to the known principles of specific protein-protein recognition.

The synthesis of a set of macromolecules, necessary for each complex, is far from being local; it occurs on the mRNA, leaving the nucleus, and thus is spread out - starting from some relatively limited space regions to chaotic synthesis along the whole cytoplasm. Exceptions are presented only by ribosomes, for which special structures exist in the very nucleus. The search for required nomenclature of macromolecules is performed by vesicles in a scanning, statistic way. The desirable variant is selected at the expense of the principle of recognition (similar to self-assembly) of specific domains of required macromolecules on complementary domains of vesicles (or the complex to be assembled in it). Target delivery takes place by the same scanning with inter-recognition of the delivered and its target (after the self-assembly took place, and domain/domains of target recognition are ready for the contact). Only the "necessary" is collected - specific macromolecules or their subsequently formed functional complexes. As a result, "along the road" of scanning the cytoplasm in the space of the cell the vesicle both collects "necessary" macromolecules, and transfers the found to the target during the same scanning. The probabilistic drift of the vesicle collects precisely the set of macromolecules from spatially separate elements, thus creating a determined structural and functional complex.

Further behavior of created assembly may be dual. Delivery to a compartment and subsequent functioning in it are possible as well as functioning in the form of a "metabolosome"on the mobile microunit itself. The metabolosome surface may contain a great number of "platforms" with both enzymes of metabolic cycles and proteins of regulatory cascades on them, which intensively move and interact on microparticles. As stated above, it is important that the density of microparticles around the nucleus is maximal, diminishing closer to the periphery of cytoplasm. What is the nature of these microparticles? And if this is how the matters stand, why have they not been found yet then? There may be various reasons. One of them is related to the probability that they are not new in principle, rather they are already described ones, with additional functions. Microvesicles with specific functions are well known in the cell: these are lysosomes, buds from Golgi apparatus, etc. They all have some common principle of structure, presenting small vesicles, the inner cavity of which is limited by the membrane. Their role is attributed to the processes, occurring inside the membrane [20]. Outside there are proteins, the tasks of which are restricted to recognition of other membranes for fusing with them. According to the assumed destination, the "platforms" should be located on the outer membrane to catch target macromolecules and organize their assembly into functionally active complexes. The presence of these "platforms" (vesicles) outside has no effect on what occurs inside. They might be seen in the pictures, but referred to the common - something that "should be".

But there is another explanation. On stained preparations such vesicles look like a rough denaturation of cytoplasm, like fixation of poor quality, i.e. they are perceived as artefacts. And apparently they are not seen on "good" preparations due to destruction. As for the ones observed, they are viewed as vesicles with common aforedescribed functions. Their adequacy is evident only while comparing the pictures from the film of a living cell and that of a "poorly fixed" one.

Therefore, the cell may be viewed as a system of structures of the whole range of stability and conservatism, which are united, organized, and maintained by highly dynamic, spatially transporting, searching and collecting system. Metabolism and signaling mainly occur not on immobile structures of the cell, but on mobile searching and collecting systems. They provide for spatial interaction of metabolic chains and signaling, located directly on them as well as between conservative structures.

The aforementioned material and its interpretation consist of experimental data and conceptual conclusions, not following the result but simply 
postulating regarding them. It might cause rejection of the concept. But it should be noted (again) that all (!) the concepts of metabolism and regulation are essentially of the same character. They are based on experimental data about the processes and it is postulated, that all these processes somehow occur in the space of the cell. And cubes, triangles, reaction products, located in required sequence and reflecting these processes, evidently demonstrate (by postulates, not by experimental material) that this is the way everything takes place. The data also show that the cell has a mechanism, capable of providing for spatial implementation of processes which were experimentally found. It is postulated to be the very mechanism and there is an attempt to explain in pure theory how the transport system of the cell may perform it. We think that the rate of trafficking for vesicles is sufficient to coordinate temporal parameters of processes. The main and central idea of the suggested explanation is the change of paradigm of the functional space of the cell.

According to the current notions, all the processes are realized by macromolecules, fixed on stationary structures, which are gathered in a proper sequence (cycles, chains, cascades, etc.) in a proper place (cellular compartments) [2], and all the participants of events come right to these compartments. As for proteins, the mechanism of penetration is considered to be leader sequences, providing transport through membranes (both external and internal). In fact, all the ideas of transport are revolving around these leader sequences. Even the possibility of protein transport in the compartment using vesicles, budded from Golgi apparatus, is based on the fact that proteins penetrate into cisterns due to the leaders. They go further in vesicles, fissioned from Golgi apparatus, and later (after the fusion of membranes) leave them for their own compartment. According to the notions, developed in the present work, everything is organized in the cell "quite in the opposite way". In general, both metabolism and signaling occur on the surface of intensively moving membrane microstructures, interacting both with immobile structures and among themselves. However, this interaction is highly dynamic in both space and time. It promotes the formation of metabolic cycles (on such mobile structures) and their contacts for full-scale functioning as well as the formation and achieving the targets by the signaling participants. These microunits are highly dynamic and scanning the space of the cell; they select necessary units of functional multimolecular complexes out of it, and they also are microcompartments, some structural units of metabolism - "metabolosomes". Not only separate molecules, but also small intracellular units may be involved in such dynamic compartments. For instance, mitochondria produce ATP and a number of other products, involved into extramitochondrial metabolism. They leave mitochondria using special transmitters, located in their membrane systems. Then they may be delivered to "the destination place" because mitochondria attach to intracellular contractile elements, therefore, they may move intensively. But it may occur in different way: microvesicles with enzymatic cycles on them bind to mitochondria, labile complexes are formed; their sizes (with the configuration of "sandwich" type) will be in the range of experimentally registered values. So, for the diameter of small vesicles is about $0.2 \mathrm{Mm}$, a total cross section of the mitochondria with vesicles is about 0.6 мm. Labile dynamic multicompartments, corresponding to the activity state and direction of cell metabolism, may appear out of such polyfunctional multimicrostructures. In the process of scanning its site of the cell, each specific microstructure collects necessary functional macromolecular complexes, provides the transmission of regulatory signals on them, functional interaction with other complexes, etc.

Metabolosome may also fulfill one more critical function - some kind of a damping device, dynamic depot, balancer of products of metabolic cycle. At any not absolutely balanced transition "from hand to hand" there will be accumulation of intermediate metabolites (or their shortage). In the microvesicle they may penetrate through its membrane, be locally kept for some time and balance this process. A living cell is not only "exchange of substances and energy", but also spatial dynamics, providing for the realization of "exchange of substances and energy". And suggested principle of organization and functioning of intracellular processes on experimentally registered highly-dynamic microvesicles allows explaining it. In 
usual, normal, everyday life of the cell there is constant inner trafficking of all its constituents. Similar constant deformation of any intracellular membrane matrix is also inevitable. Here the distances between [the] enzymes of metabolic cycles, docked in similar compartments, will change by nanometers. Precise "from hand to hand" connection becomes impossible. Therefore, all structures, where cycles are locally and independently realized, are integral: mitochondria, ribosomes, peroxisomas, etc. They preserve the precision of their content. This is exactly the way metabolosomes will behave. The cell is a marvelous system, where intense trafficking and precise stability exist at the same time.

В. А. Кордюм, В. И. Андриенко, О. А. Маслова, Н. С. Шувалова, Д. М. Иродов, Т. А. Рубан, Е. М. Сухорада, Л. И. Лихачева, С. П. Шиилевая

Фундаментальный пробел в фундаментальной биологии

Институт молекулярной биологии и генетики НАН Украины Ул. Академика Заболотного, 150, Киев, Украина, 03680

Резюме

Ставится проблема внутриклеточной пространственно-временной организации метаболизма, сигналинга и энергетического обеспечения этих процессов. Для функционирования клетки ферменты метаболических иепей, молекуль сигнальных путей, макроэрги (как единицы молекулярных взаимодействий, сопровождающихся поглощением энергии) должны находить своих партнеров и пространственно-прецизионно взаиморасполагаться. Существующие представления основаны на идеях компартментализации всех этих прочессов в виде локальных участков мембраны клеточного матрикса, на которых происходят отдельные этапы различных ичиклов. Сборка комплексов макромолекул в требуемом количестве и сочетаниях для их адекватного функиионирования в пространстве клетки в самом общем виде описывается как внутриклеточный транспорт везикул, осуществляемый подвижными элементами ичтоскелета. А внутри везикул расположен «полезный груз» - макромолекулы. Мембраны таких везикул сливаются с определенными участками мембран матрикса и таким способом перемещают макромолекулы. Любые расчеты и любые допущения не позволяют на подобной основе объяснить прецизионные формирования ферментных иепей, их взаимодействие, сигналинг и т. д. Такой транспорт макромолекул (внутри везикул) обеспечивает решение иных задач. Для объяснения поиска партнеров, формирования иепей и комплексов, образования компартментов предлагается и обосновывается кониепиия по- исково-адресных систем доставки в виде сканирующих пространство клетки микровезикул. Они собирают на своей поверхности соответствующие иепи ферментов, участков сигналинга, их взаимодей- ствия. Такие микровезикулы и являются компартментами, обеспечивающими и прецизионность процессов, и их взаимодействие.

Ключевые слова: метаболизм, клетка, компартментализаиия, везикула, транспорт макромолекул, преиизионность проиессов

В. А. Кордюм, В. І. Андрієнко, О. А. Маслова, Н. С. Шувалова, Д. М. Іродов, Т. О. Рубан, О. М. Сухорада, Л. І. Лихачева, С. П. Шпилева

Фундаментальна прогалина у фундаментальній біології

Резюме

У публікаиії поставлено проблему внутрішньоклітинної просторово-часової організаиії метаболізму, сигналінгу та енергетичного забезпечення цих процесів. Для функиіонування клітини ферменти метаболічних ланиюгів, молекули сигнальних шляхів, макроерги (як одинииі молекулярних взаємодій, що супроводжуються поглинанням енергіï) повинні знаходити своїх партнерів і мати просторово-прецизійне взаєморозташування. Існуючі уявлення засновано на ідеях компартменталізаиії усіх цих процесів у вигляді локальних ділянок мембрани клітинного матрикса, де відбуваються окремі етапи різних циклів. Збирання комплексів макромолекул у необхідній кількості і комбінаціях для їхнього адекватного функиіонування у просторі клітини у самому загальному вигляді описується як внутрішньоклітинний транспорт везикул, який здійснюється рухливими елементами цитосккелета. А всередині везикул розташований «корисний вантаж» - макромолекули. Мембрани таких везикул зливаються з певними ділянками мембран матриксу і таким чином пересувають макромолекули. Будь-які розрахунки і припущення не дозволяють на подібній основі з 'ясувати прециизійні формування ферментних ланиңюгів, їхню взаємодію, сигналінг тощо. Такий транспорт макромолекул (усередині везикул) забезпечує вирішення інших завдань. Для пояснення пошуку партнерів, формування ланцюгів і комплексів, створення компартментів пропонується $і$ обгрунтовується концепція пошуково-адресних систем доставки у вигляді скануючих простір клітини мікровезикул. Вони збирають на своїй поверхні відповідні ланцюги ферментів, ділянок сигналінгу, їхньої взаємодії. Такі мікровезикули і є компартментами, що забезпечують і прецизійність процесів, $і$ їхню взаємодію.

Ключові слова: метаболізм, клітина, компартменталізаиія, везикула, транспорт макромолекул, преиизійність процесів.

\section{REFERENCES}

1. Metzler D. E., Metzler C. M., Sauke D. J. Biochemistry: The chemical reactions of living cells / $2^{\text {nd }}$ ed.-New York: Acad. press, 2001.-Vol. 1, 2.

2. Alberts B., Johnson A., Lewis J., Raff M., Roberts K., Walter P. Molecular biology of the cell $/ 4^{\text {th }}$ ed.-New York: Garland Sci., 2002.-1616 p.

3. Ovadi J., Sacs V. On the origin of intracellular compartmentation and organized metabolic systems // Mol. Cell. Biochem.- 2004.-256-257, N 1-2.-P. 5-12. 
4. Lodish H., Berk A., Matsudaira P., Kaiser C. A., Krieger M., Scott M. P., Zipursky L., Darnell J. Molecular cell biology / $5^{\text {th }}$ ed.-New York: W. H. Freeman an Co., 2003.-1052 pp.

5. Nelson D. L., Cox M. M. Lehninger principles of bioche mistry / $4^{\text {th }}$ ed.-New York: Worth Publ., 2004.

6. Salmon E. D., Saxton W. M., Leslie R. J., Karow M. L., McIntosh J. R. Diffusion coefficient of fluorescein-labeled tubulin in the cytoplasm of embryonic cells of a sea urchin: video image analysis of fluorescence redistribution after photobleaching // J. Cell Biol.-1984.-99, N 6.-P. 2157-2164.

7. Claros M. G., Brunak S., von Heijne G. Prediction of N-termi- nal protein sorting signals // Curr. Opin. Struct. Biol.-1997.-7, N 3.-P. 394-398.

8. Watari H., Blanchette-Mackie E. J., Dwyer N. K., Glick J. M., Patel S., Neufeld E. B., Brady R. O., Pentchev P. G., Strauss J. F. $3^{\text {rd }}$. Niemann-Pick C1 protein: obligatory roles for N-termi- nal domains and lysosomal targeting in cholesterol mobilization // Proc. Natl Acad. Sci. USA.-1999.-96, N 3.-P. 805-810.

9. Gerber S. H., Sudhof T. C. Molecular determinants of regulated exocytosis // Diabetes.-2002.-51, suppl. 1.-S3-S11.

10. Mostov K., Apodaca G., Aroeti B., Okamoto C. Plasma membrane protein sorting in polarized // J. Cell Biol.-1992.-116, N 3.-P. 577-583.

11. Spang $A$. On vesicle formation and tethering in the ER-Golgi shuttle // Curr. Opin. Cell Biol.-2009.-21, N 4.-P. 531-536.

12. Pfeffer $S$. R. Multiple routes of protein transport from endoso- mes to the trans Golgi network // FEBS Lett.-2009.-583, N 23.- P. 3811-3816.

13. Jackson T. Transport vesicles: coats of many colours // Curr. Biol.-1998.-8, N 17.-R609-R612.

14. Robinson D. G., Hinz G., Holstein S. E. The molecular characte- rization of transport vesicles // Plant. Mol. Biol.-1998.- 38, N 1-2.-P. 49-76.
15. Bryksin A. V., Laktionov $P$. P. Role of glyceraldehyde-3-phosphate dehydrogenase in vesicular transport from Golgi appara- tus to endoplasmic reticulum // Biochemistry (Moscow).2008.-73, N 6.-P. 619-625.

16. Chaineau M., Danglot L., Galli T. Multiple roles of the vesicu- lar-SNARE TI-VAMP in post-Golgi and endosomal traffi- cking // FEBS Lett.-2009.-583, N 23.-P. 3817-3826.

17. Miserey-Lenkei S., Chalancon G., Bardin S., Formstecher E., Goud B., Echard A. Rab and actomyosin-dependent fission of transport vesicles at the Golgi complex // Nat. Cell Biol.- 2010.-12, N 7.-P. 645-654.

18. Angelucci S., Marchisio M., Di Giuseppe F., Pierdomenico L., Sulpizio M., Eleuterio E., Lanuti P., Sabatino G., Miscia S., Di Ilio C. Proteome analysis of human Wharton's jelly cells during in vitro expansion // Proteome Sci.-2010.-8.- P. 18.

19. Wolosewick J. J., Porter K. R. Microtrabecular lattice of the cy- toplasmic ground substance. Artifact or reality // J. Cell Biol.- 1979.-82, N 1.-P. 114-139.

20. Levine $T$., Loewen $C$. Inter-organelle membrane contact sites: through a glass, darkly // Curr. Opin. Cell Biol.-2006.-18, N 4.- P. 371-378.
UDC 579.245

Received 17.12.10 